\title{
Heterogeneity of vascular endothelial cells with relevance to diagnosis of vascular tumours
}

\author{
I Kuzu, R Bicknell, AL Harris, M Jones, K C Gatter, D Y Mason
}

\begin{abstract}
Aims: To determine the distribution of factor VIII related antigen, CD31, CD34 and CD36 in normal and malignant human vascular tissues using a panel of well characterised monoclonal antibodies.

Methods: Frozen and fixed material from a wide range of normal tissues and routinely processed material from 43 benign and malignant vascular tumours were examined. Single immunocytochemical labelling was performed using the APAAP technique. Double staining involved the sequential use of APAAP with the peroxidase method.

Results: Human vascular endothelium was antigenically heterogeneous. One of the most restricted markers was factor VIII related antigen, despite its having been widely used in diagnostic pathology as a marker of vascular endothelium and of the tumours which arise from it. Three antibodies against factor VIII related antigen, CD31 (JC70) and CD34 (QBend 10) were identified as immunostaining routinely processed, formalin fixed, paraffin wax sections. Each antibody gave different staining when tested on a range of vascular tumours, both benign and malignant.

Conclusions: A small panel of three reagents (factor VIII related antigen, CD31 (JC70) and CD34 (QBend 10)) should be used by diagnostic pathologists who want to show the presence of cells of endothelial origin in routine material.
\end{abstract}

Nuffield Department of Pathology, John Radcliffe Hospital, Headington, Oxford OX3 9DU

I Kuzu

$M$ Jones

K C Gatter

D Y Mason

ICRF Molecular

Oncology Laboratory, Institute of

Molecular Medicine,

John Radclifie Hospital

R Bicknell

A L Harris

Correspondence to:

Dr K C Gatter

Accepted for publication

31 July 1991

Vascular endothelium has an important role in coagulation, inflammation, immune response regulation, vascular tone, stromal component synthesis and angiogenesis. ${ }^{1}$ These different functions are reflected in endothelial cells which show a variety of morphological and physiological characteristics that depend on their sites or activity. ${ }^{1}$ A striking example of this is the presence of transferrin receptor on endothelium in the brain; it is absent from endothelium in other tissues of the body. ${ }^{2}$ In pathology practice, however, endothelium has been treated as a single unit and it has traditionally been thought that its immunocytochemical recognition can be achieved using antibodies against a single antigenic marker-factor VIII related antigen (FVIIIRA) or von Willebrand's factor. FVIIIRA has an important role in platelet adhesion and aggregation and is local- ised in Weibel-Palade bodies in the vascular endothelial cell cytoplasm. ${ }^{134}$ Antibodies against it generally give good staining results on larger blood vessels, but in many tissues there is frequently a lack of staining on many capillaries and sinus endothelial cells. ${ }^{5-7}$ This has been reflected in numerous studies where staining for FVIIIRA has been inconsistent in terms of numbers and type of tumours. ${ }^{357-9}$ These situations have raised many questions about the reliability of these antibodies for pathological investigations and have stimulated a search for better reagents.

Vascular endothelial cells express a number of molecules which have been well characterised-for example, CD31, CD34, CD36because they are also present on some leucocytes and have been studied extensively in the context of the leucocyte differentiation antigen workshops. ${ }^{10}$ CD31 is a member of the adhesion molecule family and is involved in platelet adhesion in inflammation and in wound healing. ${ }^{11}$ CD34 is a glycosylated transmembrane protein present on immature haematopoietic precursor cells and is believed to be involved in leucocyte adhesion and endothelial cell migration during angiogenesis. CD36 is associated with the thrombospondin receptor present on monocytes, platelets, and endothelium. ${ }^{10}$

This study was undertaken to determine the distribution of these molecules on endothelial cells throughout human tissues. The aim of this study was to determine whether one or more of these antibodies to vascular associated antigens might be better for the identification of endothelium in health and disease than FVIIIRA alone.

\section{Methods}

Fresh tissue samples from a wide range of normal tissues were obtained from the Histopathology Department of the John Radcliffe Hospital. These included tissues from tumour resection specimens and were taken as far from the tumour as possible. Most of the tissues came from different patients. These unfixed tissues were immediately snap frozen in liquid nitrogen and stored at $-70^{\circ} \mathrm{C}$. Cryostat sections $(5-8 \mu \mathrm{m})$ were then cut and collected on multi-well glass slides, dried at room temperature overnight, and fixed in acetone for 10 minutes at room temperature. The sections were either stained immediately or stored, wrapped in aluminium foil at $-20^{\circ} \mathrm{C}$, until staining.

Normal tissues examined in cryostat sections comprised: kidney, liver, lung, adrenal, 
Table 1 Monoclonal antibodies used in this study

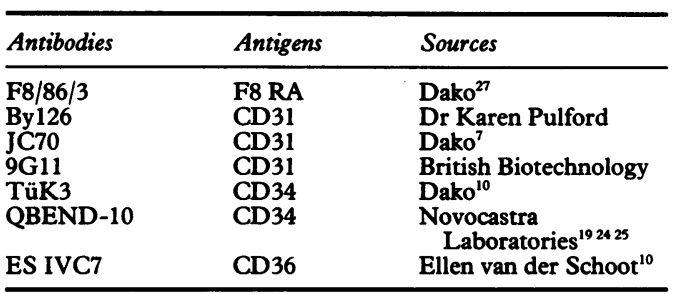

thyroid, ovary, testis, skin, thymus, spleen, reactive lymph node, reactive tonsil, brain (cerebellum and cerebrum) and pancreas.

Paraffin wax tissue sections were prepared from routine blocks stored in the Histopathology Department, John Radcliffe Hospital, Oxford, and included all of the main tissues of the body. Several vascular tumours were also studied. These comprised six angiosarcomas, five Kaposi's sarcomas, 12 haemangiomas, two lymphangiomas, four angiokeratomas, three pyogenic granulomas, three angiolipomas, three myxomas and one example each of haemangioepithelioma, angiofibroma, glomus tumour, chemodectoma, and submucosal venous dilatation of the colonic mucosa. All tissues were fixed in unbuffered formol saline before paraffin wax embedding. For convenience, some multiblock preparations were prepared as previously described. ${ }^{12}$

The monoclonal antibodies that were used in our study are listed in table 1 .

The alkaline phosphatase-anti alkaline phosphatase (APAAP) method was used for single immunocytochemical staining. ${ }^{13}$ Double staining was performed with selected antibodies, using a peroxidase method for the first antibody followed by the APAAP immunoalkaline phosphatase technique for the second. ${ }^{14}$

\section{Results}

\section{CRYOSTAT SECTIONS}

The results obtained on cryostat sections with the antibodies used in this study on vascular endothelium in different types of tissues are summarised in table 2. Details of the results are given below.

\section{FVIIIRA}

FVIIIRA immunostaining of endothelium depended on whether it was evaluated in

Table 2 Reactivity of endothelial cells in cryostat sections of normal tissues

\begin{tabular}{|c|c|c|c|c|c|}
\hline Tissues & Endothelium & F8 & $C D 31$ & $C D 34$ & $C D 36$ \\
\hline Kidney & $\begin{array}{l}\text { Glomerular capillaries } \\
\text { Interstitial capillaries } \\
\text { Interlobular vessels } \\
\text { Larger veins } \\
\text { Larger arteries }\end{array}$ & $\begin{array}{l}- \\
-+ \\
++ \\
+++ \\
+++\end{array}$ & $\begin{array}{l}+++ \\
+++ \\
+++ \\
+++ \\
+++\end{array}$ & $\begin{array}{l}++ \\
++ \\
++ \\
++ \\
++\end{array}$ & $\begin{array}{l}- \\
++ \\
++ \\
++ \\
++\end{array}$ \\
\hline Liver ${ }^{\star}$ & $\begin{array}{l}\text { Sinusoidal endothelium } \\
\text { Central veins } \\
\text { Portal veins } \\
\text { Portal arteries }\end{array}$ & $\begin{array}{l}+ \\
+ \\
++ \\
++\end{array}$ & $\begin{array}{l}++ \\
+++ \\
+++ \\
+++\end{array}$ & $\begin{array}{l}+T \\
++ \\
++ \\
++ \\
++\end{array}$ & $\begin{array}{l}+T+ \\
+++ \\
+++ \\
++ \\
++\end{array}$ \\
\hline Lung & $\begin{array}{l}\text { Alveolar septal capillaries } \\
\text { Venules } \\
\text { Veins } \\
\text { Arteries }\end{array}$ & $\begin{array}{l}- \\
++ \\
+++ \\
+++\end{array}$ & $\begin{array}{l}+++ \\
+++ \\
+++ \\
+++\end{array}$ & $\begin{array}{l}+ \\
+ \\
++ \\
++\end{array}$ & $\begin{array}{l}+++ \\
+++ \\
++ \\
++\end{array}$ \\
\hline Adrenal & $\begin{array}{l}\text { Capillaries } \\
\text { Post capillary venules } \\
\text { Larger veins } \\
\text { Larger arteries }\end{array}$ & $\begin{array}{l}- \\
+ \\
++ \\
++\end{array}$ & $\begin{array}{l}++ \\
+++ \\
+++ \\
+++\end{array}$ & $\begin{array}{l}++ \\
++ \\
++ \\
++\end{array}$ & $\begin{array}{l}+++ \\
++ \\
++ \\
++\end{array}$ \\
\hline Thyroid & $\begin{array}{l}\text { Capillaries } \\
\text { Larger veins } \\
\text { Larger arteries }\end{array}$ & $\begin{array}{l}++(50 \%) \\
++ \\
++\end{array}$ & $\begin{array}{l}+++ \\
+++ \\
+++\end{array}$ & $\begin{array}{l}++(100 \%) \\
++ \\
++\end{array}$ & $\begin{array}{l}+++(100 \%) \\
++ \\
++\end{array}$ \\
\hline Ovary & $\begin{array}{l}\text { Small vessels and capillaries } \\
\text { Large arteries } \\
\text { Large veins }\end{array}$ & $\begin{array}{l}+ \\
+++ \\
+++\end{array}$ & $\begin{array}{l}+++ \\
+++ \\
+++\end{array}$ & $\begin{array}{l}+ \\
++ \\
++\end{array}$ & $\begin{array}{l}+++ \\
-\end{array}$ \\
\hline Testis & $\begin{array}{l}\text { Capillaries } \\
\text { Venules } \\
\text { Larger arteries } \\
\text { Larger veins }\end{array}$ & $\begin{array}{l}x^{2} \\
++ \\
++ \\
+++ \\
++\end{array}$ & $\begin{array}{l}++ \\
++ \\
+++ \\
+++\end{array}$ & $\begin{array}{l}T+ \\
++ \\
++ \\
++ \\
++\end{array}$ & $\begin{array}{l}+++ \\
+++ \\
+++ \\
+++\end{array}$ \\
\hline Skin & $\begin{array}{l}\text { Vessels in papillary dermis } \\
\text { Vessels in deep dermis }\end{array}$ & $\begin{array}{l}+++ \\
+++\end{array}$ & $\begin{array}{l}+++ \\
+++\end{array}$ & $\begin{array}{l}+ \\
+\end{array}$ & $\begin{array}{l}++ \\
++\end{array}$ \\
\hline Lymph node & $\begin{array}{l}\text { Sinuses } \\
\text { HEV } \\
\text { Other venules } \\
\text { Other capillaries } \\
\text { Trabecular and hilar veins } \\
\text { Trabecular and hilar arteries }\end{array}$ & $\begin{array}{l}- \\
+++ \\
+++ \\
+ \\
+++ \\
+++\end{array}$ & $\begin{array}{l}+++ \\
+++ \\
+++ \\
+++ \\
+++ \\
+++\end{array}$ & $\begin{array}{l}++ \\
++ \\
++ \\
++ \\
++ \\
++\end{array}$ & $\begin{array}{l}++ \\
+++ \\
+++ \\
+++ \\
+++ \\
+\end{array}$ \\
\hline Tonsil & $\begin{array}{l}\text { HEV } \\
\text { Other capillaries } \\
\text { Other venules } \\
\text { Larger arteries } \\
\text { Larger veins }\end{array}$ & $\begin{array}{l}++ \\
-+ \\
++ \\
+++ \\
+++\end{array}$ & $\begin{array}{l}+++ \\
+++ \\
+++ \\
+++ \\
+++\end{array}$ & $\begin{array}{l}++ \\
++ \\
++ \\
++ \\
++\end{array}$ & $\begin{array}{l}+++ \\
+++ \\
+++ \\
+\end{array}$ \\
\hline Thymus & $\begin{array}{l}\text { Medullar capillaries } \\
\text { Cortical capillaries } \\
\text { HEV } \\
\text { Interlobular tissue veins } \\
\text { Interlobular arteries }\end{array}$ & $\begin{array}{l}+++ \\
++ \\
++ \\
++ \\
+++\end{array}$ & $\begin{array}{l}+++ \\
+++ \\
+++ \\
+++ \\
+++\end{array}$ & $\begin{array}{l}++ \\
++ \\
++ \\
++ \\
++\end{array}$ & $\begin{array}{l}+++ \\
+++ \\
+++ \\
+++ \\
?\end{array}$ \\
\hline Spleen & $\begin{array}{l}\text { Sinus } \\
\text { Red pulp capillaries } \\
\text { Arteria centralis } \\
\text { Trabecular veins } \\
\text { Trabecular arteries }\end{array}$ & $\begin{array}{l}++ \\
+++ \\
++ \\
++ \\
++\end{array}$ & $\begin{array}{l}+++ \\
+++ \\
+++ \\
+++ \\
+++\end{array}$ & $\begin{array}{l}- \\
++ \\
++ \\
++ \\
++\end{array}$ & $\begin{array}{l}+++ \\
+++ \\
+++ \\
+++ \\
+\end{array}$ \\
\hline Cerebrum and cerebellum & $\begin{array}{l}\text { Capillaries } \\
\text { Larger vessels }\end{array}$ & $\begin{array}{l}+++ \\
+++\end{array}$ & $\begin{array}{l}++ \\
++\end{array}$ & $\begin{array}{l}++ \\
++\end{array}$ & \\
\hline Pancreas & $\begin{array}{l}\text { Capillaries } \\
\text { Venules } \\
\text { Larger arteries } \\
\text { Larger veins }\end{array}$ & $\begin{array}{l}+ \\
++ \\
++ \\
++\end{array}$ & $\begin{array}{l}+++ \\
+++ \\
+++ \\
+++\end{array}$ & $\begin{array}{l}++ \\
++ \\
++ \\
++\end{array}$ & $\begin{array}{l}++t \\
++t \\
- \\
-\end{array}$ \\
\hline
\end{tabular}

*The liver vessels showed different strengths of staining with the CD31 and CD34 antibodies. 
Figure $1 A-D$ show the outer edge of lymph node cortex including a lymph node sinus stained with, respectively, FVIIIRA $(A), C D 31(B), C D 34$ (C) and CD36 (D) to illustrate the heterogeneous staining pattern of the endothelial cells.

Figure $1 E, F, G$

Angiosarcoma stained for CD31 with antibody JC70 (E), CD34 with antibody $Q$ Bend-10 $(F)$ and FVIII RA (G).

Figure $1 \mathrm{H}$ Normal adrenal double stained for FVIIIRA in brown and $C D 31$ in red. The smaller capillaries are only labelled by $C D 31$ (red) whereas the larger vessels, probably postcapillary venules, are double stained and express both $C D 31$ and FVIII RA.

Figure 1 I Normal kidney double stained for

FVIIIR $A$ in brown and CD31 in red. FVIIIRA is only present on venules and small capillaries whereas $C D 31$ shows extensive labelling of

glomerular capillaries and the fine interstitial capillary network between the renal tubules.

Figure $1 \mathrm{~J}$ Double staining with CD31 and FVIIIRA antibodies on reactive lymph node shows the different vessel staining with the CD31 and FVIIIRA antibodies on the same section where it is compared separately on fig $1 A$ and $B$ (peroxidase followed by $A P A A P$ double staining method).

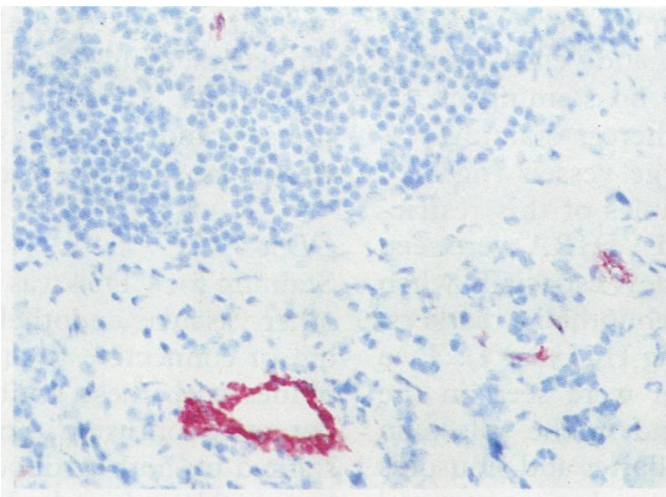

A

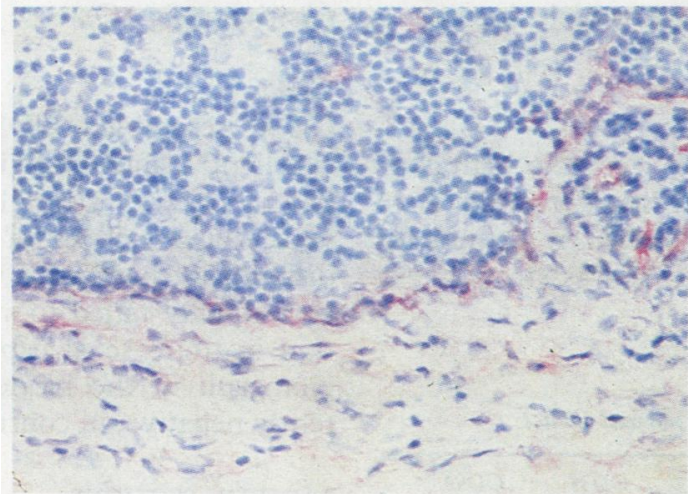

C

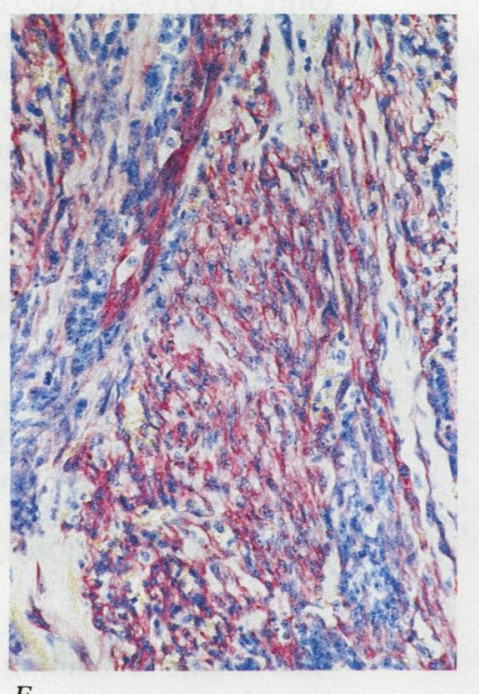

E

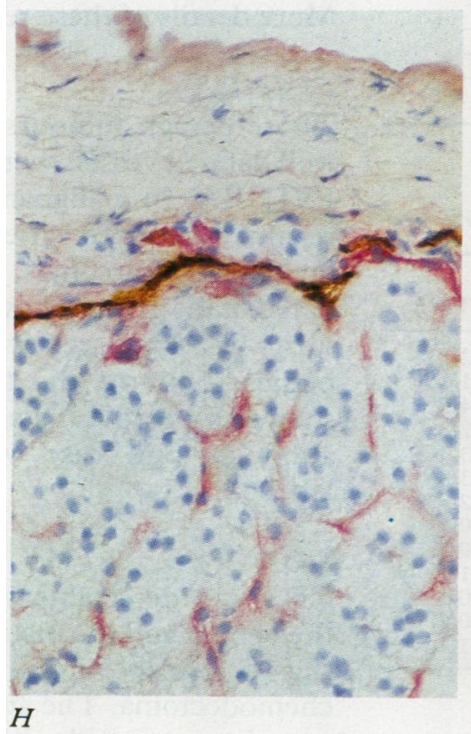

F

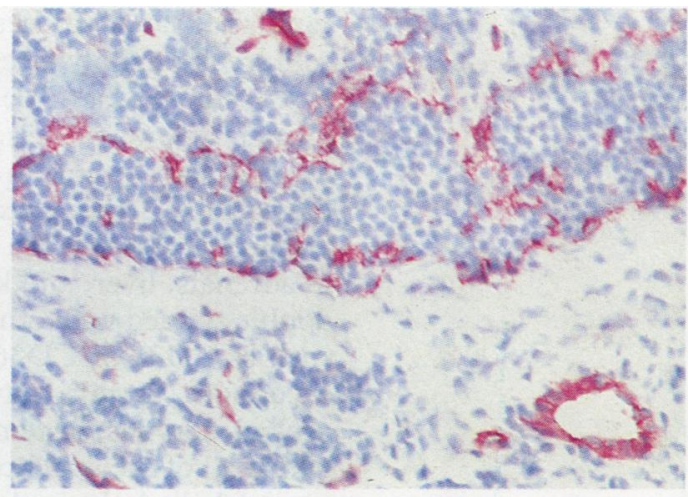

B

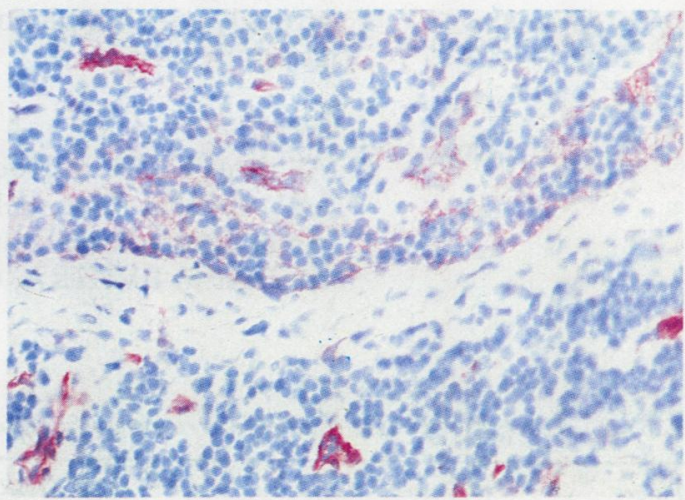

D
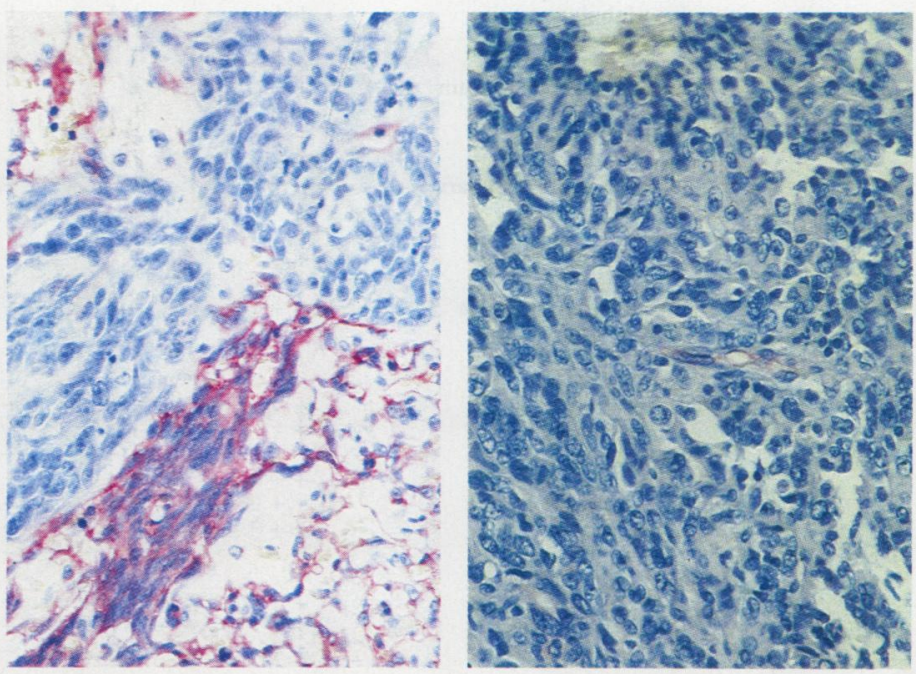

G

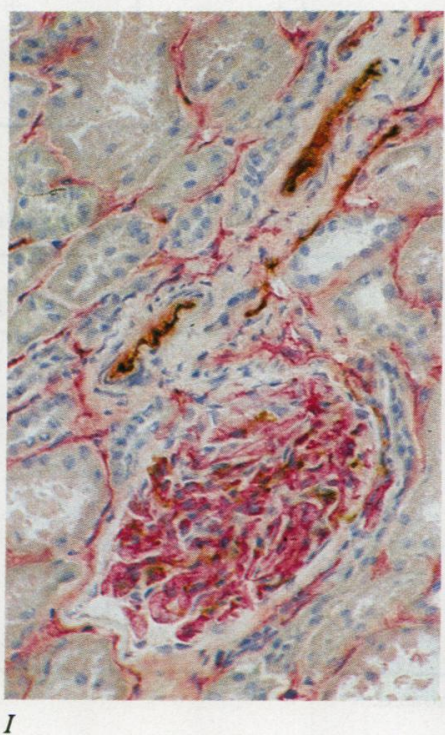

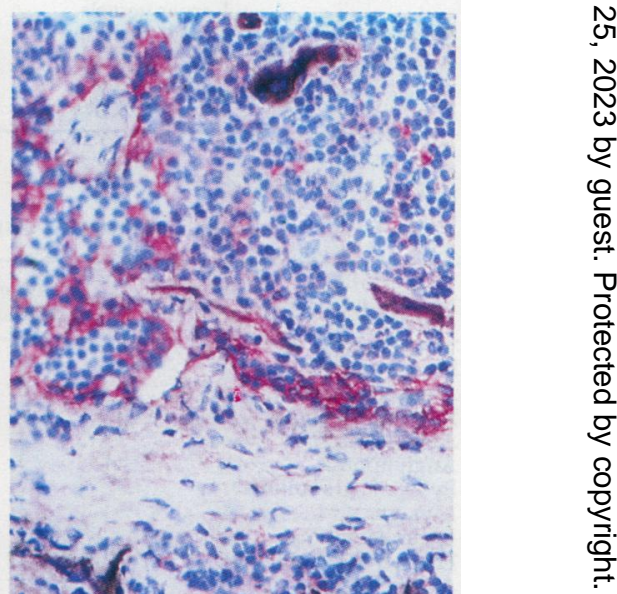


capillaries and sinuses or in large vessels, comprising mainly arteries and veins. In most tissues there was little or no staining of the former type of vessels, whereas staining was usually very strong in large vessels (fig 1A). Particularly striking examples of this restriction in the distribution of FVIIIRA were seen in adrenals, liver, and kidney, especially when double stained with other endothelial markers, such as CD31 or CD36 (fig H, I and J). Two exceptions to this pattern were seen in the central nervous system and in the spleen in which all of the small capillaries and sinusoids were labelled. Indeed, the spleen contrasted strongly with lymph node in which sinuses are generally unstained.

\section{$C D 31$}

All three CD31 antibodies were excellent general vascular endothelial markers and gave virtually identical results on frozen sections. In contrast to FVIIIRA, CD31 was strongly ex-

Table 3 Reactivity of endothelial cells in routinely processed normal tissues

\begin{tabular}{|c|c|c|c|c|}
\hline Tissues & Vessels & FVIIIRA & $C D 31$ & $C D 34$ \\
\hline Kidney & $\begin{array}{l}\text { Glomerular capillaries } \\
\text { Interstitial capillaries } \\
\text { Interlobular vessels } \\
\text { Larger veins } \\
\text { Larger arteries }\end{array}$ & $\begin{array}{l}- \\
+- \\
++ \\
++ \\
++\end{array}$ & $\begin{array}{l}++ \\
++ \\
++ \\
++ \\
++\end{array}$ & $\begin{array}{l}+ \\
+ \\
+ \\
+ \\
+\end{array}$ \\
\hline Liver & $\begin{array}{l}\text { Sinusoidal endothelium } \\
\text { Central veins } \\
\text { Portal arteries } \\
\text { Portal veins }\end{array}$ & $\begin{array}{l}+- \\
++ \\
++ \\
++\end{array}$ & $\begin{array}{l}+ \\
++ \\
++ \\
++\end{array}$ & $\begin{array}{l}\dot{+} \\
+ \\
+ \\
+\end{array}$ \\
\hline Lung & $\begin{array}{l}\text { Alveolar septal capillaries } \\
\text { Venules } \\
\text { Larger veins } \\
\text { Larger arteries }\end{array}$ & $\begin{array}{l}- \\
+ \\
+ \\
+\end{array}$ & $\begin{array}{l}+ \\
+ \\
+ \\
+\end{array}$ & $\begin{array}{l}+ \\
+ \\
-\end{array}$ \\
\hline Adrenal & $\begin{array}{l}\text { Capillaries } \\
\text { Post capillary venules } \\
\text { Larger arteries } \\
\text { Larger veins }\end{array}$ & $\begin{array}{l}\overline{+}+ \\
++ \\
++\end{array}$ & $\begin{array}{l}+ \\
+ \\
+\end{array}$ & $\begin{array}{l}++ \\
++ \\
++ \\
++\end{array}$ \\
\hline Thyroid & $\begin{array}{l}\text { Capillaries } \\
\text { Larger veins } \\
\text { Larger arteries }\end{array}$ & $\begin{array}{l}\overline{+} \\
+\end{array}$ & $\begin{array}{l}+ \\
+ \\
+\end{array}$ & $\begin{array}{l}+ \\
+ \\
+\end{array}$ \\
\hline Tonsil & $\begin{array}{l}\text { Capillaries } \\
\text { HEV } \\
\text { Larger arteries } \\
\text { Larger veins }\end{array}$ & $\begin{array}{l}- \\
+++ \\
+++ \\
+++\end{array}$ & $\begin{array}{l}++ \\
++ \\
++ \\
++\end{array}$ & $\begin{array}{l}++ \\
++ \\
++ \\
++\end{array}$ \\
\hline Spleen & $\begin{array}{l}\text { Sinus } \\
\text { Red pulp capillaries } \\
\text { Arteria centralis } \\
\text { Trabecular veins } \\
\text { Trabecular arteries }\end{array}$ & $\begin{array}{l}+ \\
+ \\
++ \\
++ \\
++\end{array}$ & $\begin{array}{l}++ \\
++ \\
+++ \\
+++ \\
+++\end{array}$ & $\begin{array}{l}- \\
+ \\
- \\
-\end{array}$ \\
\hline $\begin{array}{c}\text { Cerebrum and } \\
\text { cerebellum }\end{array}$ & $\begin{array}{l}\text { Capillaries } \\
\text { Larger vessels }\end{array}$ & $\begin{array}{l}++ \\
++\end{array}$ & $\begin{array}{l}+ \\
+\end{array}$ & + \\
\hline Pancreas & $\begin{array}{l}\text { Capillaries } \\
\text { Venules } \\
\text { Larger veins } \\
\text { Larger arteries }\end{array}$ & $\begin{array}{l}- \\
++ \\
++ \\
++\end{array}$ & $\begin{array}{l}+ \\
+ \\
+ \\
+\end{array}$ & $\begin{array}{l}+- \\
+- \\
+- \\
+-\end{array}$ \\
\hline
\end{tabular}

Table 4 Reactivity of routinely processed benign and malignant vascular tumours

\begin{tabular}{lllll}
\hline Tumours & $\begin{array}{l}\text { Number of } \\
\text { cases }\end{array}$ & $\begin{array}{l}\text { QBEND } 10 \\
\text { (CD34) }\end{array}$ & $\begin{array}{l}\text { JC70 } \\
\text { (CD31) }\end{array}$ & FVIII \\
\hline Haemangioma & 12 & $10 / 12$ & $12 / 12$ & $12 / 12$ \\
Angiosarcoma & $66^{\star}$ & $2 / 6$ & $5 / 6$ & $1 / 16 \dagger$ \\
Kaposi's sarcoma & 5 & $5 / 5$ & $5 / 5$ & $4 / 5 \ddagger$ \\
Angiokeratoma & 4 & $2 / 3$ & $4 / 4$ & $2 / 3$ \\
Angiolipoma & 3 & $2 / 3$ & $3 / 3$ & $3 / 3$ \\
Pyogenic granuloma & 3 & $1 / 1$ & $2 / 2$ & $3 / 3$ \\
Myxoma & 3 & $2 / 3$ & $3 / 3$ & $2 / 3$ \\
Lymphangioma & 2 & $1 / 2$ & $0 / 2$ & $0 / 2$ \\
Haemangioepithelioma & 1 & $1 / 1$ & $0 / 0$ & $0 / 0$ \\
Angiofibroma & 1 & $0 / 1$ & $0 / 1$ & $1 / 1$ \\
Glomus tumour & 1 & $0 / 1$ & $0 / 1$ & $0 / 1$ \\
Chemodectoma & 1 & $1 / 1$ & $1 / 1$ & $1 / 1$ \\
Submucosal venous dilatation, colon & 1 & & &
\end{tabular}

*Five were undifferentiated, one was differentiated.

tThe staining was very weak.

tOne of the cases stained very weakly. pressed in all endothelial cells including capillaries, sinuses and larger vessels (fig 1B). The major exceptions to this were hepatic sinuses and splenic sinusoids which were weakly labelled when compared with CD36.

\section{$C D 34$}

Staining for CD34 was not as strong as for the other vascular endothelial markers, and staining of connective tissue and basement membranes with these antibodies was a source of potential confusion. Splenic sinuses were unstained by both antibodies; the sinuses in the liver and lymph node showed weak but definite positivity (fig 1C).

\section{$C D 36$}

CD36 resembled CD31 in that it was an excellent panendothelial cell marker. Like CD31, it was strongly expressed in small vessels and sinuses of spleen and liver, but differed in that larger vessels were weaker or occasionally failed to stain. A striking exception in the case of capillary staining was the glomeruli in the kidney which were consistently negative, in contrast to CD31.

\section{PARAFFIN SECTIONS}

Normal tissues

Only FVIIIRA, CD31 (antibody JC70), and CD34 (antibody QBend 10 ) reacted with formalin fixed, paraffin wax embedded material (table 3). Staining of fixed tissues was usually weaker than in comparable cryostat sections. This was particularly noticeable for CD31 on adrenal capillaries which were often weak and difficult to demonstrate even with considerably amplified immunostaining procedures, whereas staining was clearly positive in cryostat sections. In most normal tissues FVIIIRA gave strong staining of endothelial cells, but as noted for cryostat sections, the number and type of vessels stained were fewer than with the other antibodies, especially when compared with CD31 (antibody JC70).

Tumours

The results of staining 43 routinely processed vascular tumours are summarised in table 4. More details of these results are given below.

\section{FVIIIRA}

Those benign tumours which contain mature well defined vessels were almost all positive for FVIIIRA. In malignant vascular tumours the results were more varied (fig 1G). Only one of the six angiosarcomas, the most well differentiated of the group, showed any positivity and it was weak compared with the other two antibodies. Four of the five Kaposi's sarcomas showed positive staining for FVIIIRA, although one case was extremely weakly labelled.

\section{CD31}

CD31 was detectable with antibody JC70 in all the benign and the malignant vascular tumours (fig 1E), except for the glomus tumour and the chemodectoma. The angiosarcoma recorded as negative was poorly differentiated and of some 
interest as immunolabelling was restricted to very weak cytoplasmic staining in a small number of tumour cells, contrasting with the more typical membrane staining seen in the other angiosarcomas.

\section{CD34}

All the cases of Kaposi's sarcoma showed very strong staining of the spindle and endothelial cells in the vascular spaces with the antibody against CD34 (QBend 10). Immunostaining, however, was more restricted in the other cases, with most of the angiosarcomas (fig 1F) and some of the benign vascular tumours being unlabelled.

The tumour cells in the chemodectoma and glomus tumour were not stained by any of the antibodies, although the vascular spaces between the tumour cells that contained an endothelial cell lining were positive with all of the antibodies. Both of the lymphangioma cases were negative with all of the antibodies.

\section{Discussion}

Far from being a homogeneous tissue, vascular endothelium has a very different antigenic profile, depending on the type of vessel and the tissue in which it lies. Such findings are not unexpected, considering the differing function of endothelial cells in different tissues, such as the maintenance of the blood-brain barrier, the importance of small vessels in endocrine organs (adrenal, thyroid), renal glomeruli and high endothelial venules of lymph nodes and spleen.

Antibodies against FVIIIRA were initially thought to be good markers for endothelial cells, but when a wider range of antibodies is studied, it is clear that FVIIIRA is restricted in its ability to recognise endothelial cells. The variability of FVIIIRA expression on endothelial cells may be related to the maturation status of the cell. ${ }^{381516}$ This would explain the limited value of FVIIIRA antibodies in diagnostic pathology, because many vascular tumours, especially malignant ones, will be at a stage of differentiation not recognised by such antibodies. ${ }^{8917}$

CD31 is a glycoprotein expressed during the differentiation of myelomonocytic cells which has been shown by immunoprecipitation to be identical with the PECAM-1 molecule ${ }^{11}$ found on endothelial cells, platelets, and the surface of monocytes and granulocytes. Molecular genetic studies show that PECAM-1's sequence (and thus that of CD31 as well) have strong similarities to Cell Adhesion Molecule (CAM) members of the Ig gene superfamily ${ }^{11}$ and for this reason $\mathrm{CD} 31$ has also been termed ENDOCAM ${ }^{18}$ It is thought to be important in the initiation of inflammation and wound healing. ${ }^{11}$ Of the three CD31 antibodies tested in this study, only JC70 recognises an epitope that is resistant to formalin fixation, as previously reported by Parums et al $1990 .^{7}$ This antibody therefore has potential value in diagnostic practice because the spectrum of its reactivity is wider than that of other vascular endothelial markers. Indeed, antibody JC70 was the only reagent which reacted with virtually all malig- nant vascular tumours. In particular, its ability to immunostain angiosarcomas is of diagnostic value.

CD34 is a heavily glycosylated transmembrane protein which is expressed on immature human lymphopoietic precursor cells and lost progressively with maturation. ${ }^{19}$ It is believed to act as a stage specific rather than lineage specific antigen. ${ }^{19}$ The antigen has also been reported to be present on endothelial cells. ${ }^{10}$ The sharing of this antigen between haematopoietic cells and endothelial cells has been used as an argument for the common origin of these cells. ${ }^{20}$ Immunoelectron microscopic studies show that it is concentrated on membrane processes, most of which interdigitate between adjacent endothelial cells, though it is absent from the tight junctions themselves. ${ }^{21}$ Although its exact function has not been elucidated, it has been argued that it might be involved in leucocyte adhesion or endothelial cell migration during angiogenesis. As yet this has not been validated. ${ }^{2021}$ Of the two monoclonal CD34 antibodies used in this study, QBend 10 gave stronger and clearer staining on cryostat sections and had the added advantage of recognising its antigen on paraffin wax embedded sections. Previous studies of QBend 10 on routinely processed vascular tumours are in broad agreement with the present findings, that QBend 10 is an excellent marker of Kaposi's sarcoma ${ }^{22-25}$ but is only occasionally present on angiosarcoma and can be absent from some benign vascular tumours. ${ }^{22}$

CD36 is associated with the thrombospondin receptor which acts as an anti-angiogenic factor and can be identified in platelets, endothelial cells, and monocytes. ${ }^{102}$ As previously reported, ${ }^{10} \mathrm{CD} 36$ antibodies show strong reactivity with endothelial cells in most capillaries and small vessels but are absent from larger vessels such as arteries and veins. The capillaries in renal glomeruli were also negative. The antibody ES-IVC7 available for this study was not reactive on routinely processed tissues nor have there been any reports of CD36 antibodies showing this property.

In conclusion, the present study has examined the immunoreactivity of endothelial cells in a wide range of normal and neoplastic tissues with a panel of antibodies against well characterised antigens, and has emphasised the antigenic heterogeneity of endothelial cells. Three antibodies against FVIIIRA, CD31, CD34, gave reliable immunostaining of formalin fixed, paraffin wax embedded sections. A small panel comprising these three reagents constitutes a comprehensive and reliable method for identifying tumours of vascular origin in routine pathology practice.

This work was supported in part by the Soroptimist International of Europe and the Leukaemia Research Fund. We are grateful to Dr DV Parums for advice and tissue samples, and to Drs KA Pulford and E van der Schoot for antibodies.

1 Fajardo L. Special report. The complexity of endothelial cells. Am J Clin Pathol 1989;92:241-50.

2 Jeffries WA, Brandon MA, Hunt SV, Williams AF, Gatter KC, Mason DY. Transferrin receptor on endothelium of brain capillaries. Nature 1984;312:162-3.

3 Enzinger FM, Weiss SW. Soft tissue tumours. Second ed. Missouri: CV Mosby Company, 1988 
4 Tannenbaum TH, Rick ME, Shafer B, Gralnick HR. Subendothelial matrix of cultured endothelial cells contains fully processed high molecular weight von Willebrand factor. J Lab Clin Med 1989;113:372-8.

5 Kinjo T, Takashi M, Miyake K, Nagura H. Phenotypic heterogenity of vascular endothelial cells in the human heterogenity of vascular endothelial cell

6 Lenzi R, Alpini G, Liu MH, Rand JC, Tavolini N. Von Willebrand factor antigen is not an accurate marker of rat Willebrand factor antigen is not an accurate marker of rat and guinc.

7 Parums DV, Cordell JL, Micklem K, Heryet AR, Gatter KC, Mason DY. JC70: a new monoclonal antibody that detects vascular endothelium associated antigen on routinely processed tissue sections. J Clin Pathol 1990; 43:752-7

8 Bohling T, Paetau A, Ekblom P, Haltia M. Distribution of endothelial and basement membrane markers in angiogenic tumors of the nervous system. Acta Neuropathol genic tumors

9 Yasunuga C, Sueishi K, Ohgami H, Suita S, Kawanami T. Heterogenous expression of endothelial cell markers in infantile hemangioendothelioma. Am J Clin Pathol 1989; 91:673-81

10 Knapp W, Dorken B, Gilks WR, et al. Leucocyte typing IV. Oxford: Oxford University Press, 1989.

11 Newman PJ, Berndt MC, Gorski J, et al. PECAM-1 (CD31) cloning and relation to adhesion molecules of the immunoglobulin gene superfamily. Science 1990;247:1219-22.

12 Battifora $\mathrm{H}$. The multitumour (sausage) tissue block: Noval method for immunohistochemical antibody testing. Lab Invest 1986;55:244-8.

13 Gatter K, Falini B, Mason D. The use of monoclonal antibodies in histopathological diagnosis. In: Antony PP $\mathrm{MR}$, ed. Recent advances in histopathology. London: Longmans, 1984:35-67.

14 Mason D, Abdulaziz Z, Falini B, Stein H. Double immunoenzymatic labelling. In: Polak J, Van Noorden S, Bristol $\mathrm{T}$, eds. Immunocytochemistry: Practical applications in pathology and biology. 1984:113-28.

15 Rosai J. Ackerman's surgical pathology Seventh ed. Missouri: CV Mosby, 1989:1580-1.

16 Zhu PD, Gu Z. Observation of the activity of factor VIII in the endometrium of women with regular menstrual cycles. Hum Reproduct 1988;3:273-5.

17 Kagawa H, Fujimoto S. Electron microscopic and immunocytochemical analyses of Weibel-Palade bodies in the human umbilical vein during pregnancy. Cell Tissue Res 1987;249:557-63.

18 Fawcett J, Harris A, Bicknell R. Isolation and properties in culture of human adrenal capillary endothelial cells. Biochem Biophys Res Commun 1991;174:903-8.

19 Watt SM, Karhi K, Gatter K, et al. Distribution and epitope analysis of the cell membrane glycoprotein (HPCA-1) associated with human hematopoietic progenitor cells. Leukemia 1987;1:417-26.

20 Schlingemann RO, Rieltveld FJR, de Wall RMV, et al. Leukocyte antigen CD34 is expressed by a subset of cultured endothelial cells on the endothelial abluminal microprocesses in the tumor stroma. Lab Invest 1990; 62:690-6.

21 Fina L, Molgaard HV, Robertson D, et al. Expression of the CD34 gene in vascular endothelial cells. Blood 1990; 75:2417-26.

22 Fletcher C, Ramani P. OBend-10: A useful but by no means specific, marker of Kaposi's sarcoma. J Pathol 1990; specific,
162:273.

23 Dhillon A, Sankey E, More L. QBend10: A new immunostain for the routine diagnosis of Kaposi's sarcoma. $J$ Pathol 1990;162:274.

24 Sankey E, More L, Dhillon A. QBend-10: A new immunostain for the routine diagnosis of Kaposi's sarcoma. J Pathol 1990;161:267-71.

25 Ramani P, Bradley N, Fletcher C. QBEND/10, a new monoclonal antibody to endothelium: assessment of its diagnostic utility in paraffine sections. Histopathol 1990; 17:237-42.

26 Koo CH, Mason DY, Miller R, Ben EJ, Sheibani K, Rappaport $H$. Additional evidence that "plasmacytoid Tcell lymphoma" associated with chronic myeloproliferative disorders is of macrophage/monocyte origin. Am J Clin ive disorders is of macrop

27 Naiem M, Gardes J, Abdulaziz Z, et al. The value of immunohistological screening in the production of monoclonal antibodies. J Immunol Methods 1982;50:145-60. 